\title{
Bowel loops and eyelid droops
}

\author{
Jamie Spiegelman MD, David W. Cescon MD, Yael Friedman MD, Brie V. Mazza MD, \\ John W. Austin MSc PhD, Anita Rachlis MD, Brian J. Murray MD
}

\begin{abstract}
A patient presented with a small-bowel obstruction associated with signs and symptoms of botulism. Fecal cultures were positive for viable Clostridium botulinum. This case emphasizes the importance of a broad differential diagnosis and doing a complete examination to account for all signs and symptoms.
\end{abstract}

The case: A 45-year-old man who was previously healthy presented to the emergency department with acuteonset abdominal distension and mild blurry vision. Despite self-induced vomiting, his abdominal distension worsened. A small-bowel obstruction was diagnosed based on his clinical presentation and the results of radiography (Figure 1). A computed tomography scan of the patient's abdomen confirmed the obstruction, but did not add any further information. Despite nasogastric suctioning for 12 hours, the patient's abdomen continued to distend, bowel sounds became diminished and signs of peritonitis (guarding, tenderness) appeared. To avoid bowel perforation, an exploratory laparotomy was performed. No obvious cause of the obstruction was identified.

A neurologist was consulted 5 days later to assess the patient's worsening neurologic symptoms, including ptosis (Figure 2), diplopia, dysphagia, aphonia and dry mouth. On examination, the patient's vital signs were normal. Performing the Valsalva manoeuvre did not change his heart rate The patient had bilateral paralysis of cranial nerves 3, 4, 6, 7, 9 and 10. The patient's pupils were initially dilated but they were sluggishly reactive to light. One day later, his pupils were unreactive to light (Figure 3). Neck flexion was weak, but appendicular strength was preserved. A neurophysiological assessment with repetitive nerve stimulation was performed, which showed an electro-incremental response on high-frequency stimulation, which was suggestive of a presynaptic disorder.

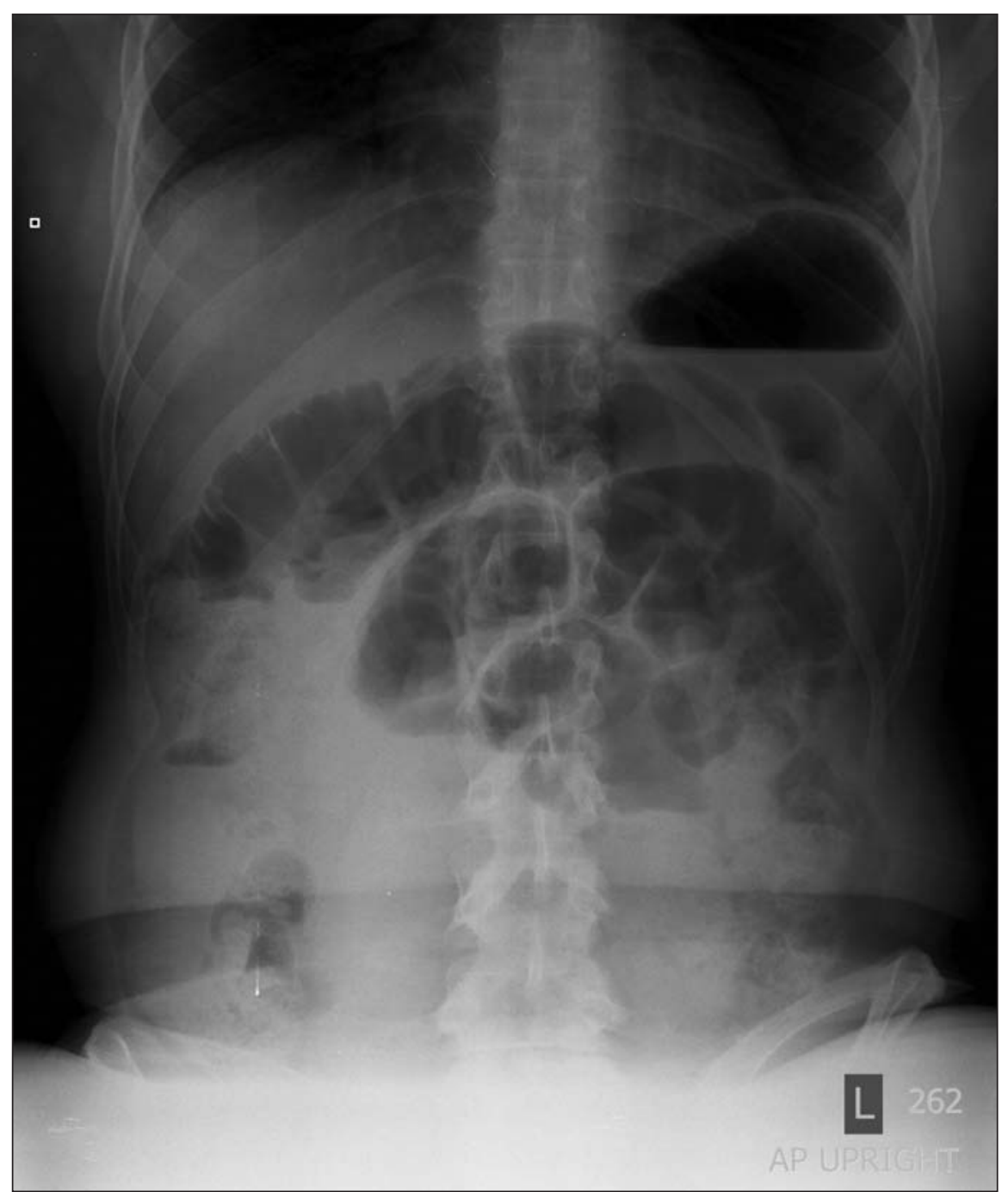

Figure 1: Abdominal radiograph obtained while the patient was in an upright position. Note the small-bowel obstruction with multiple air-fluid levels.

Botulism was highly suspected based on the clinical presentation and the neurophysiological findings. Serum, stool and gastric contents were sent for testing. A detailed history revealed no exposure to suspicious foods, and he had no sick contacts. Public health was notified im-

From the Department of Medicine (Spiegelman, Cescon, Mazza), Division of Neurology (Friedman, Murray), Division of Infectious Diseases (Rachlis), University of Toronto, Sunnybrook Health Sciences Centre, Toronto, Ont.; Bureau of Microbial Hazards, Food Directorate, Health Canada (Austin), Ottawa, Ont. 
Table1: Characteristics of the natural forms of botulism

\begin{tabular}{|c|c|c|c|c|}
\hline Type & Cause & Examples of sources & Clinical manifestations* & Confirmation of the diagnosist \\
\hline Foodborne & $\begin{array}{l}\text { - Ingestion of food } \\
\text { contaminated by } \\
\text { preformed } \\
\text { botulinum toxin }\end{array}$ & $\begin{array}{l}\text { - } \quad \text { Canned food } \\
\text { - } \text { Fermented fish }\end{array}$ & $\begin{array}{l}\text { Beginning } 12-36 \mathrm{~h} \text { after ingestion: } \\
\text { - Nausea, vomiting, abdominal } \\
\text { pain, diarrhea and dry mouth } \\
\text { - Cranial nerve involvement } \\
\text { (blurry vision, diplopia, } \\
\text { nystagmus, ptosis, dysphagia, } \\
\text { dysarthria and facial weakness) } \\
\text { - Descending muscle weakness }\end{array}$ & $\begin{array}{l}\text { Detection of botulinum } \\
\text { neurotoxin in serum, } \\
\text { stool, gastric aspirate } \\
\text { or food } \\
\text { - Isolation of C. botulinum } \\
\text { from stool or gastric aspirate } \\
\text { - Electrophysiologic } \\
\text { investigations may be useful }\end{array}$ \\
\hline $\begin{array}{l}\text { Infant } \\
\text { (1 wk-12 mo) }\end{array}$ & $\begin{array}{l}\text { Ingestion of spores } \\
\text { that colonize the } \\
\text { host's gastro- } \\
\text { intestinal tract and } \\
\text { release toxins }\end{array}$ & $\begin{array}{l}\text { - Honey } \\
\text { - Environmental } \\
\text { dust }\end{array}$ & $\begin{array}{l}\text { - Constipation } \\
\text { - Weakness } \\
\text { - Difficulty feeding } \\
\text { - Descending or global hypotonia } \\
\text { - Drooling } \\
\text { - Anorexia } \\
\text { - Irritability } \\
\text { - Weak cry }\end{array}$ & $\begin{array}{l}\text { - Isolation of } C \text {. botulinum } \\
\text { Detection of botulinum } \\
\text { neurotoxin in feces } \\
\text { - Presumptive diagnosis } \\
\text { should be made based } \\
\text { on clinical presentation } \\
\text { and electrophysiologic } \\
\text { results }\end{array}$ \\
\hline Wound & $\begin{array}{l}\text { Infection of a } \\
\text { wound by } \\
\text { Clostridium } \\
\text { botulinum, } \\
\text { which produces } \\
\text { a neurotoxin }\end{array}$ & $\begin{array}{l}\text { - Puncture wounds } \\
\text { - Abscess } \\
\text { - Abrasions } \\
\text { - Drug use (e.g., } \\
\text { "black tar" } \\
\text { heroin, inhaled } \\
\text { cocaine) }\end{array}$ & $\begin{array}{l}\text { - Similar to the manifestations } \\
\text { of foodborne botulism but no } \\
\text { gastrointestinal symptoms }\end{array}$ & $\begin{array}{l}\text { - Confirmed by electro- } \\
\text { physiologic results } \\
\text { - Presence of toxins } \\
\text { in the wound } \\
\text { - Fever } \\
\text { - Leukocytosis }\end{array}$ \\
\hline Colonization & $\begin{array}{l}\text { - Production of toxin } \\
\text { in the gastro- } \\
\text { intestinal tract of an } \\
\text { infected adult host }\end{array}$ & $\begin{array}{l}\text { - Ingestion } \\
\text { unknown (no } \\
\text { preformed toxin } \\
\text { found in suspect } \\
\text { foods) }\end{array}$ & $\begin{array}{l}\text { - Similar to the manifestations } \\
\text { of infant and foodborne } \\
\text { botulism }\end{array}$ & $\begin{array}{l}\text { - Isolation of C. botulinum } \\
\text { - Detection of botulinum } \\
\text { neurotoxin in feces } \\
\text { - Presumptive diagnosis } \\
\text { should be made based } \\
\text { on clinical presentation } \\
\text { and electrophysiologic } \\
\text { results }\end{array}$ \\
\hline
\end{tabular}

*Clinical manifestations common to all forms of botulism include: absence of a fever, hemodynamic stability (early), generally symmetric neurological deficits, and responsiveness with a lack of sensory deficits except potentially blurry vision.

tOnce any type is suspected, careful monitoring and treatment should be initiated immediately, including clinical evaluation of respiratory system compromise, including pulse oximetry, spirometry and arterial blood gas measurement. Intubation may be required. Antitoxin or immune globulin should be started immediately. Antibiotics are not indicated, except for wound botulism.

mediately. We administered antitoxin based on his clinical presentation and the the progression of his pupillary symptoms. There was no subsequent progression of his symptoms. The patient's bowel sounds returned 6 days after the exploratory laparotomy. The patient received nutrition through a nasogastric tube until his neurologic deficits improved. Speech sounds and other deficits gradually improved over several weeks.

Initial samples of the patient's serum, feces and gastric contents as well as food sources were all negative for botulinum neurotoxin and viable Clostridium botulinum. Two fecal samples, taken about 2 and 8 weeks after the onset of symptoms, both tested positive for viable $C$. botulinum type $B$. Because the results were positive for $C$. botulinum type $B$ and negative for toxins, we suspected colonization botulism rather than foodborne botulism. The patient received no further therapy because his symptoms were im- proving. He remained in hospital with supportive care for 1 month until his dysphagia resolved.

Botulism is a rare neuroparalytic illness caused by a neurotoxin produced by $C$. botulinum. Botulinum neurotoxin causes irreversible inhibition of acetylcholine release, which affects both the autonomic and somatic systems. ${ }^{1}$ Although rare, it remains an important public health concern. From 2000 to 2005, there was an average of 5.8 cases of botulism reported each year in Canada. ${ }^{2-5}$ A complete review of the patient's systems and a physical examination, including cranial nerves, will help to establish the diagnosis. ${ }^{6}$

There are 4 natural forms of clinical botulism: foodborne, infant, wound and adult intestinal colonization (Table 1). Foodborne botulism is caused by ingestion of food contaminated with 1 of 4 serotypes of neurotoxin (A, B, E or F). 


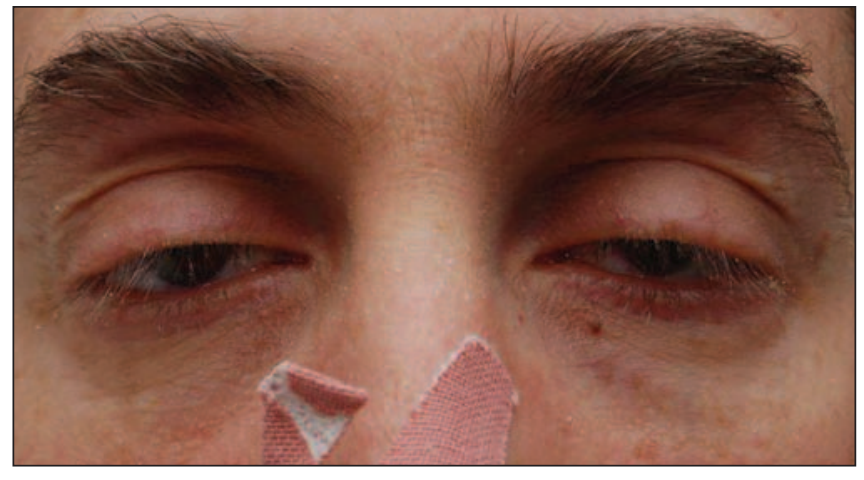

Figure 2: The patient had ptosis of both eyes.

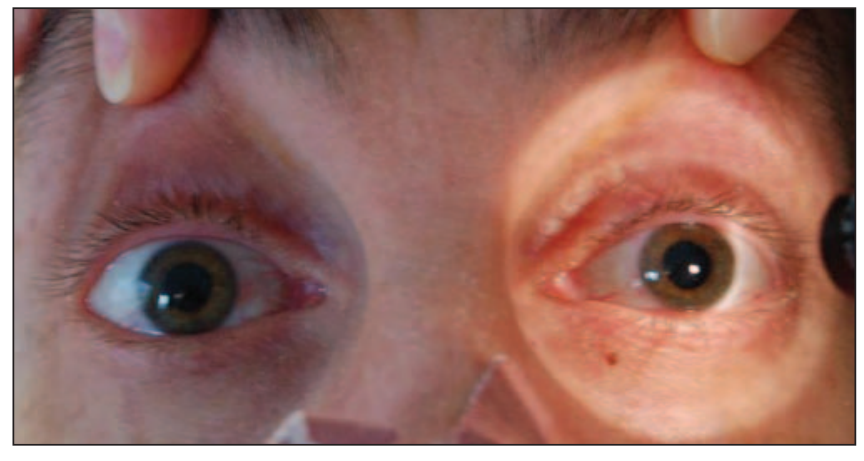

Figure 3: Six days after the patient presented with abdominal distension and blurry vision, his pupils became unresponsive to light.

Foodborne illness in adults can be caused by a variety of foods. Symptoms typically begin 12-36 hours after ingestion and include vomiting and diarrhea, followed by 1 or more of ptosis, visual disturbance, dilated and fixed pupils, dysphagia, dry mouth and dysphonia. These symptoms may progress to a descending symmetric flaccid paralysis in an alert afebrile person. Constipation may occur later in the presentation. Infant botulism results from ingestion of spores, followed by germination and colonization in the intestine. Wound botulism may result from contamination of wounds by soil or injection of illicit drugs. The symptoms of wound botulism are similar to that of the foodborne form, however, vomiting and diarrhea do not occur. Adult intestinal colonization botulism is caused by ingestion of spores that germinate in the colon. The risk factors for adult intes- tinal colonization botulism include bowel abnormality, previous bowel surgery, Meckel diverticulum, Crohn disease and long-term antimicrobial therapy.

Once botulism is suspected, the local public health unit and the Botulism Reference Service for Canada should be notified immediately. Samples of the patient's feces and gastric contents as well as suspect foods should be tested for botulinum neurotoxin and viable $C$. botulinum. Serum should be tested for botulinum neurotoxin. After appropriate samples are collected, treatment with antitoxin should be considered. Antitoxin against type A, B and E is typically administered. The benefit of this therapy is greatest within the first 24 hours after the onset of symptoms. Respiratory monitoring and support is essential. If flaccid paralysis occurs, it can not be reversed by antitoxin; however, the antitoxin neutralizes circulating toxins and prevents progression of symptoms.

This article has been peer reviewed.

Competing interests: None declared.

\section{REFERENCES}

1. Brook I. Botulism: the challenge of diagnosis and treatment. Rev Neurol Dis 2006;3:182-9.

2. Public Health Agency of Canada. Notifiable diseases summary. Can Commun Dis Rep 2002;28:50.

3. Public Health Agency of Canada. Notifiable diseases summary. Can Commun Dis Rep 2004;30:182.

4. Public Health Agency of Canada. Notifiable diseases summary. Can Commun Dis Rep 2005;31:238.

5. Public Health Agency of Canada. Notifiable diseases summary. Can Commun Dis Rep 2006;32:200.

6. Cai S, Singh BR, Sharma S. Botulism diagnostics: from clinical symptoms to in vitro assays. Crit Rev Microbiol 2007;33:109-25.

Teaching cases are brief case reports that convey clear, practical lessons. Preference is given to common presentations of important rare conditions, and important unusual presentations of common problems. Articles start with a brief summary (100 words) outlining the case and its relevance to a general audience. The case presentation follows (500 words maximum) as well as a discussion of the underlying condition (1000 words maximum). Generally, up to 5 references are permitted and visual elements (e.g., tables of the differential diagnosis, clinical features or diagnostic approach) are encouraged. Written consent from patients for publication of their story is a necessity and should accompany submissions. See information for authors at www.cmaj.ca.

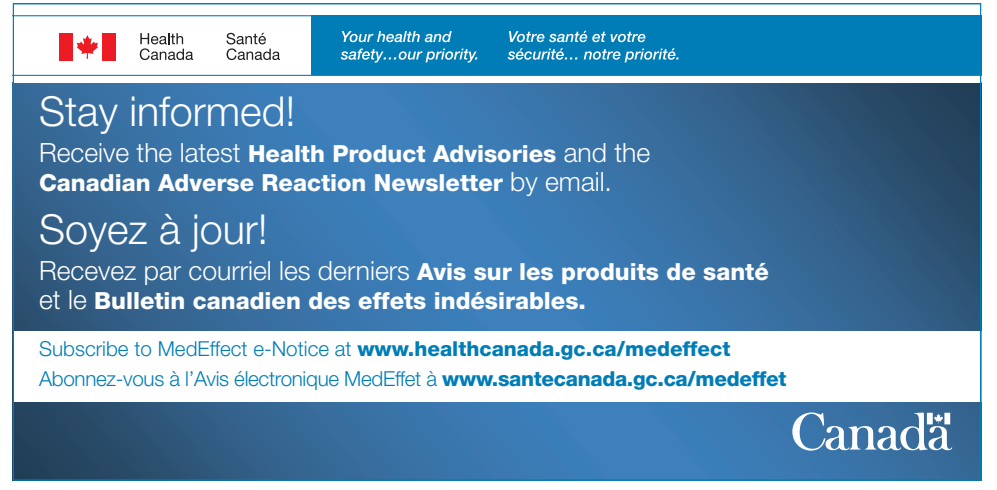

